\title{
Toward Reinvigorating an Ethnolinguistic Approach to the Study of 'Kin Terms': A View from Nascent-based Zuni Relational Terminology
}

\author{
Linda K. Watts
}

\section{Introduction}

I welcome this opportunity to honour the work of Harold K. Scheffler by suggesting that his semantic extensionist approach to the cross-cultural study of kin terminology could be expanded to a broader linguistic field than the domain of lexical-referential, genealogically based relational terminology forms. A more holistic linguistic account of relational terminology is discussed with regard to the relational terminology system in use at Zuni Pueblo about which the author and other scholars have elsewhere made relevant contributions (Kroeber 1917; Ladd 1979; Schneider and Roberts 1956) or have analysed directly (Watts 1992, 2000).

In 1917, Alfred Kroeber asserted that the Zuni peoples' use of their own so-called kinship terminology system was 'utterly slovenly' and 'by rule of thumb' (76-77). In view of observational data he collected on 'errata' of kin-term applications according to the anthropological perspective that the Zuni kin-term system comprises a 'modified Crow' type- 
that is, distinguishing mother's mother from father's mother as included in one sort of Crow system-Kroeber assumed that Zunis had been erratically affected by linguistic acculturation to a 'thoroughly bilateral' pattern (ibid.: 48). This resulted, he thought, in speakers often 'violating' their native principles of kin-term usage in favour of bilateral as versus matrilineal extensions.

The fact is, the Zuni cares remarkably little for system or theory. 'He is an opportunist. He has the broad, vague outlines of his kinship system well in mind; but he is not in the least interested in following out basic principles into consistent detail' (Kroeber 1917: 76).

Thus, for instance, Kroeber observed that speakers might address someone of a father's sister (Schneider and Roberts 1956:3) or a father's older sister's daughter (Kroeber 1917: 54) kin type with possessively marked forms of the relational term tsitda, associated in an ethnogenealogically defined Crow system with M/MZ kin types. This so-called 'bilateral' principle of usage was, in 1917, neither pervasive nor was it systemically diagnosticthen or since-of the nature of Zuni kin-term usage 'errata'. Speakers in 1917 and since were often also addressing and referring to their maternal side genealogical +2 generation grandmothers as $t$ sitda, a term culturally associated at Zuni with a senior generation, matricentric suprahousehold group- (or clan-) based, socially proximal female. An elder female sibling or even a friend's mother or grandmother who adopts, raises, or is highly supportive to a person may also be designated and addressed with appropriate possessive constructions as one's Tsitda. ${ }^{1}$ In 1986, I spoke with a centenarian who had been called from a boarding school in Albuquerque around the turn of the century to assume the position of Tsitda to her mother's newborn son because her mother had died in childbirth. This woman remained Tsitda to her genealogical younger brother all her life, and he remained Aktsek'i ('young household-group boy') and later Ts'awak'i ('mature' or 'kiva-initiated household-group' 'teen' or 'older boy') to her. I asked if this woman had ever explained her genealogical relationship to her Ts'awak'i. After some confusion about why I was asking this, she answered simply: 'That's possible, I guess; but I will always be his Tsitda'.

Shift forward to 1979 with Edmund Ladd's reappraisal of Zuni kin-term usages from a native perspective. Ladd was a native, fluent Zuni-speaking linguistic and cultural anthropologist. Contrary to Kroeber's grim and

1 I shall from here on capitalise Zuni household-based role designations. 
rather contemptuous-seeming assessment of Zuni peoples' 'slovenly, irrational' use of their own kin-term system-a vital component of Zuni language use altogether, even today-Ladd explained native cultural principles of alternation in Zuni kin-term usages that revealed how factors of relative social distance, relative familiarity, and degrees of relative household based and/or ceremonial seniority — that is pragmatic factorstrump genealogical factors in accounting for the systemic, situational use of so-called kin terms by Zuni speakers.

Ladd demonstrated how a speaker might indexically mark degrees of relative social—and not necessarily genealogical at all—proximity by using Zuni relational kin terms either inclusively or exclusively, often applying so-called kin terms to nongenealogical relatives who are socially proximal (see Watts 2000: 55), or applying them to indicate ceremonial affinity such as kiva group comembership or 'godparental' medicine society (or Catholic) sponsorship rather than as genealogical markers.

The Zuni relational particle stem form hotda has been ethnogenealogically associated with MM/MMZ. Yet informants from one household group have told me that in their extended household-group history they have chosen not to use any form of this particle for a specific maternal grandaunt. This is due to a disagreement over land inheritance between their maternal grandmother (whom they address as Tsitda, not Hotda, and who owned the house they were raised in) and one of her sisters, who did not reside therein as an adult (Watts 2000: 129-32). Members from each side of the fission to this day no longer exchange or refer to one another with direct relational kin-particle forms at all, employing the Zuni relational terminology system principle of exclusion mentioned above that Ladd (1979) described.

Another Zuni informant described a long telephone conversation she had engaged in with her genitor. This man offered to give her so many sheep if only she would agree to address him as datchu (in Crow terms, referring to one's father/father's brother kin types) in public, especially at ceremonial settings. She refused because he had not been socially proximal with her since leaving her mother's household when she was young. She used situationally appropriate forms of datchu both in reference and in address to her mother's second (in-household living) husband, and she and her children utilised relational terminology appropriately with all of this inmarried man's maternal and extended household-group members. Rather than regarding these usages as polysemic metaphorical extensions of focal 
genealogical referents, this woman stated emphatically about her genitor, 'He has never been a Datchu or 'hom ( $1^{\text {st }}$ sg. poss.) datchu' to me'. This same woman also explained to me that rather than using the direct Zuni relational expression 'hom oyemshi to refer to her first husband whom she had separated from, she would refer to him only indirectly using the teknonymous relational expression 'hom ts'awak'i 'an datchu' ( $1^{\text {st }} \mathrm{sg}$. poss. 'older boy-of-household' $3^{\text {rd }}$ sg. poss. Datchu).

I found that English referential expressions such as 'my mother' were sometimes linguistically accommodated in place of the Zuni expression hom tsitda; for example, in reference to a woman who was the subject's genetrix but who had not served as an adequately socially-proximal mater. In these cases generally the subject would address and might refer to her maternal grandmother or to an older sister or aunt-whichever female had been her primary caregiver while growing up-as her possessively marked Tsitda.

So far then we find, in contrasting Kroeber's with Ladd's accounts of Zuni kin terminology, two at times apparently diametrically opposed interpretations of the facts with regard to both referential and address forms. Zunis are 'slovenly' and 'chaotic' in their application of their modified-Crow kin terms, or conversely, Zunis maintain a flexible, pragmatic, role-based system of social semiotic nomenclature which has allowed their traditional domestic and ceremonial household groups to persist and indeed to flourish despite stochastic variation in householdgroup membership composition for over seven centuries.

Still, there is a bigger canvas to be painted. What if the focus on describing a Zuni ethnogenealogically based kin-term system was culturally inappropriate from the start? As David Schneider (1984) arguably likewise demonstrated for the Trukese of Yap—and as he made observations about earlier himself regarding Zuni (Schneider and Roberts 1956)—it could well be that a kinship-based analysis deriving from Lewis Morgan's 1871 and W.H.R. Rivers' 1910 'genealogical method' is culturally inadequate as a semantic frame of reference for eliciting data about how people refer to and address one another at Zuni.

Several scholars-notably including Ellen Basso (1973), Schneider (1980, 1984), Hansjakob Seiler (1980, 1982), Anthony Wallace (1970), Susan Bean $(1975,1978)$, and Roger Keesing $(1969,1970)$ - have investigated the dimension of address-terminology systems as a sociolinguistic 
endeavour complementary with the analysis of referential kin term systems. Kinship terminology has since Rivers (1910)—notwithstanding contrary viewpoints associated with A.M. Hocart (1937), Rodney Needham (1962), and Edmund Leach (1958), among others (see Service 1985) — been based primarily upon the elicitation of referential usages of genealogical nomenclature (e.g. 'What do you call your [genealogical kin type]?'). Address-terminology usages, by contrast, comprise a range of indexical-symbolic shifter forms which might include morphosyntactic variants of kin-term forms but also exceed these, varying pragmatically in face-to-face encounters.

Bean (1978; also see 1975), a student of Harold Scheffler, conducted a sociolinguistic investigation of address terminology of Kannada speakers in South India, in addition to conducting an extensionist-based analysis of Kannada kin classification. Bean sees address terminology as comprising a pragmatic system of speech markers - an indexical-symbolic, deictic system. After focusing her study initially on 'pure referential' kin-term vocabulary, Bean analysed the full range of linguistic forms in use. Bean discovered culturally meaningful and socially relevant principles of usage in the Kannada address terminology system that, simply put, would elude a more narrow genealogical-referential approach to kin terms.

Bean (1978: 111) includes shortened forms of Kannada kin terms along with nonkinship related second person pronouns, personal names and status terms in the Kannada address terminology system. She accounts for semantically significant features of the address forms using situational criteria, including social distance, sex of addressee and seniority. Her separate treatment (1975) of a wide array of generalised and metaphorical applications of the Kannada term amma (M/MZ per a Dravidian genealogical translation) reveals pragmatic patterns of use in face-to-face discourse. Most often, Bean finds that Kannada speakers prefer to address social relatives with nomenclature other than kinship-based expressions altogether. Hence, her study arrives at a wider linguistic analysis of both kin-classification and address-based relational terminology than would a study of referential kin terms alone.

From a linguistics perspective, relational terminology comprises a higherorder, more-inclusive ethnolinguistic domain than either a genealogically based approach to referential kin classification or a sociolinguistic study of address usages. As early as 1923, Franz Boas, in his treatment of 'The relationship system of the Vandau' (in Mozambique), recognised 
that referential kin terms-if we should methodologically isolate such a vocabulary at all in an a priori manner-represent but one heuristically possible component of a broader, more genuinely universal linguistic field of relational terminology, available in all languages. Maurice Bloch's 'The moral and tactical meaning of kinship terms' (1971), Francis Conant's 'Jarawa kin systems of reference and address' (1961), Murray Leaf's (1971) analysis of the semantics of Punjabi kin terms, and Marc Swartz's emphasis on the situational use of kin terminology among the Trukese (1960: 397) also approached kin terms qua a broader system of relational terminology 'shifters'. For example:

Sometimes, however, more than one role is called for and on Truk this is accomplished by being able to shift the kin category membership. Given the possibility of such shifting, the kin terms cannot be taken to mean only a certain genealogical relationship. The properties which people have that bring them to be classed together are not only sex, age, generation, and so on, but also their standing in various situations or contexts, and to understand the use of these terms the situational determinants must be analyzed (ibid.: 397).

Still, none of the studies cited above examines an entire relational terminology system from a comprehensive ethnolinguistic or social semiotic perspective. Linguistic analysis of a total relational terminology system, I will go so far as to assert, is what linguistics requires for an adequate investigation of how people utilise the full potentials of their linguistic system for purposes of social classification and pragmatic social interaction. From this vantage point, anthropology has been unnecessarily constrained by the misguided notion of genealogical kin-term elicitation as being a logical prerequisite or primary domain for the study of a relational terminology system and by the concept of kinship itself as a universally prototypical semantic domain for social classification. This approach limits empirical access to a full range of relational terminology forms utilised in the pragmatics of social interaction.

My point is that the entire field of so-called kinship studies in social anthropology has been based on incomplete linguistic data elicitation procedures resulting in, hence, artificially delimited ethnosemantic analyses (see Goodenough 1956; Wallace 1970; Wallace and Atkins 1960; also see Carsten 2000; Holland 2004). While this problematic is embedded implicitly within some of the challenges contained in Schneider's A Critique of the Study of Kinship (1984), Schneider has also not recognised the broader linguistic problem. 
It is unfortunate, then, that linguistics has been appealed to and is often applied to the limited data of kin terms collected by ethnogenealogical and sociolinguistic methods as if such analyses would comprise an adequate linguistic-systemic account. Such a study requires collecting and observing a full range of linguistic forms-in-use employed to accomplish both referential-semantic social classification generally, as well as indexical-symbolic pragmatic social interaction. While the linguistic scope of relational terminology forms vary typologically from language to language, they are likely to include at least minimally: pronominal systems, personal names, nicknames, kin terms (or, wider relational particle forms where semantically relevant), household-based or landholding-based role terminology, ceremonial-status terminology and usage protocols, occupational-status forms and principles of use, self- and otherintroductive phraseology, 'Indian' or initiatory statuses and names, etc. See Linda Watts for a social semiotic account of the range of linguistic options available within the Zuni relational terminology system in 1986 (2000: 61-75).

A relational terminology system includes all lexical and grammatical forms-along with their morphosyntactic variants and contextappropriate reciprocals - of nomenclature and propositional expressions utilised within a particular linguistic and cultural system. The linguistic composition and native criteria for functional selection and syntactic typological expression of these forms (i.e. for referential, introductive, polite or impolite address functions, ceremonial formulaic use, etc.) all may be documented and analysed within a systemic framework of use in relation to whole-language typology in order to arrive at a comprehensive systemic analysis.

\section{A nascent-based view of Zuni relational terminology}

In The Social Semiotics of Relational Terminology at Zuni Pueblo (Watts 2000; also Watts 1997), I approach this sort of analytic purview regarding the Zuni relational terminology system from a social semiotics frame of reference (Fawcett 1984; Halliday 1978). This approach allows me to arrive at a revisionist account of Zuni social organisation, social classification and pragmatic address and reference as based on household group-related rather than essentially genealogical prototypicality and ethnosemantics. 
Folk definitions, best exemplar focality data, and reported and observed usages and reciprocals of Zuni relational nomenclature that I collected at Zuni in 1986 analytically bear out this interpretation (Watts 1992, 1997, 2000).

Alfred L. Kroeber in 'Zuni kin and clan' (1917), went further than to mechanically apply Rivers's genealogical method. Kroeber elicited data from Zuni informants about referential Zuni kin terms. Yet, to his credit as an ethnographer, he also took note of direct observational and interview data involving actual usages of not only these elicited kin-term forms but also of usages pertaining to social classification and address that would not technically be included within the semantic domain of kinship vocabulary. As Stanley Newman aptly noted in his 'Zuni dictionary' (1958), Zuni language includes a broader-than-genealogically defined, lexically specialised domain pertaining to pragmatically significant social classification. This lexical-pragmatic domain of 'relational particle' forms incorporates but also notably supersedes kin-term forms.

Thus, Kroeber identified household-based relational nomenclature (see Figure 33), including k'yakwen'ona, people of one's mother's-or natal-household (k'yakwenne); dakinne, mother's husband's or one's recognised Datchu's natal household; a:tashbina:we, 'elders' of a household, including deceased ancestral elders (along with okkyana:we, adult women of the household; and ottsina:we, adult men of the household); and chawe, children of the household). Kroeber also identified (Figure 33) relational particle forms referring to some specific household-related affines and their households, including: ula:kwe, wife's husband's household; dala:kwe, husband's wife's natal household; and dala:ki, marriedin daughter's husband. Kroeber (1917: 70-71) also noted reciprocal ceremonial exchanges of relational status forms (suffixed by $+m o$ ) that include some of the so-called kin-term derived forms along with some purely ceremonial lexemes.

Figure 33 shows Zuni relational terminology associated with members of an interlinked Zuni household group system comprised of one's natal or core household and interlinked affinal households of a Tsitda's (maternal caregiver) husband's natal household and the natal household of a Tsitda's brother's wife, representing much of the household-based nomenclature observed by Kroeber. Each of these households may further be associated with an extended, suprahousehold group, including usually matrilineally extended 'clan' households insofar as relations are socially maintained or recognised. 


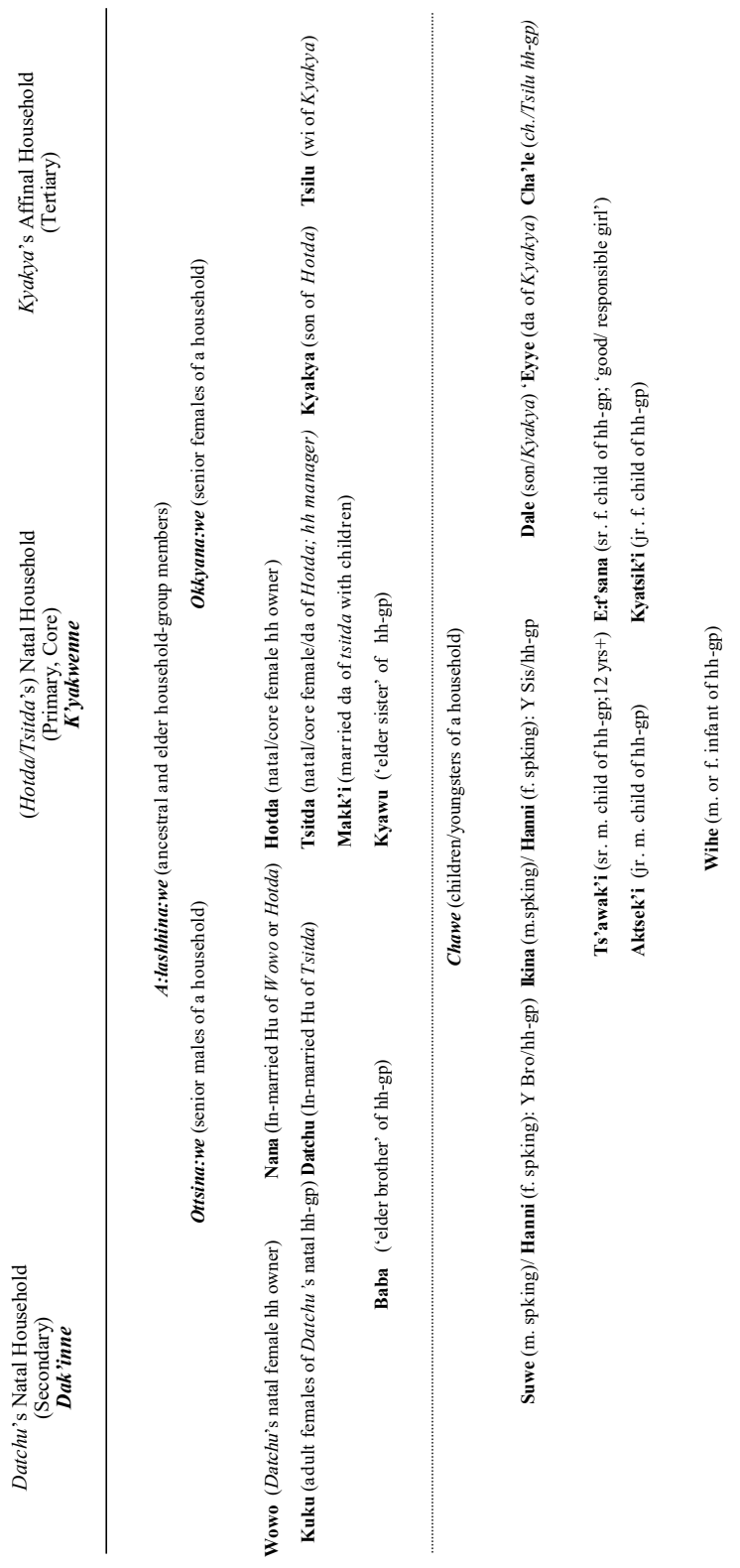

Figure 33. Zuni household-group roles

Note: $\mathrm{m} .=$ male, $\mathrm{f} .=$ female. $\mathrm{Wi}=$ wife, $\mathrm{Hu}=$ husband, $\mathrm{da}=$ daughter, $\mathrm{ch} .=$ child. Upper case relational terms are household-group role terms. Additional household-group (hh-gp) terms include ula:kwe (husband's natal household), dala:kwe or dala:k'l (wife's people or natal household), and dak'i:kwe or dak'inne (people of father's natal household).

Source: Created as original for this article by @ Linda Watts. 
Newman recognised in his 'Zuni dictionary' (1958) and later affirmed in Zuni Grammar (1965) that the so-called Zuni kin terms Kroeber had elicited via the genealogical method should be considered as not semantically distinct or privileged members of a wider inflectional class of 'relational particles' that function as 'active nouns'. Relational particles in Zuni comprise an inflectional class that behaves and is treated distinctively with regard to morphology and syntax. They are inflected for number as a distinctive class and they alternate in usage between possessively marked predicative (or relationship-establishing) and possessively unmarked (or labelling) stem or reduced forms.

Hence, the so-called kin terms Kroeber identified at Zuni are not simply 'nouns' as are English kin terms; rather, they alternate between stem or inflected shortened stem forms of relational particles and several degrees of more fully predicative expressions, depending on degrees of social proximity, kinds of settings and actual social relations.

Similarly as Seiler demonstrated for Cahuilla's labelling/absolutive versus descriptive relational expressions (1980, 1982), Zuni relational terminology forms are used according to cultural-pragmatic principles involving situationally indexical alternation involving labelling versus relationship-establishing relational particle forms. These relational particle variants are also systemically interconnected with pronominal forms (independent or affixed), personal names, 'Indian names', nicknames, slang forms and ceremonial status forms within a unified social semiotic system of 'meaning potential' (see Halliday 1978). That is, depending upon the cultural setting and the degree of actual social proximity obtaining between interlocutors or speakers, addressees and/or referents, a Zuni relational particle usage will be interpreted as situationally unmarked (i.e. neutral) or marked within that setting and for that immediate relation.

Thus, for example, the expression 'Lukkya hom Tsitda' [This- [goal] (is) she-who-is-TSITDA-to-me] contrasts situationally as a relationshipestablishing expression with the shortened address usage, 'Tsitd', which is a nonpossessively marked, phonologically reduced relational particle stem form. The latter form is used most appropriately in direct address to a socially proximal addressee within a familiar (i.e. at home) setting (Watts 2000: 49). 
A case in point is the use of the Zuni form homme (<hotda [Eng. geneal. transl, mother's mother/mother's mother's sister] +mme [noun class sg. suffix]) used in address to an elderly female (Newman 1955: 62-63). This term may be used appropriately within one's familial household setting to address a socially proximal cohousehold group, elder-senior female. In this context it is a polite, familiar, intimate form of address. However, the same form used outside the home to address an elderly female with whom one has no close or familial social tie is an impolite, youth slang usage translating roughly as 'rigid, wooden old woman'. This is because the suffix $+m m e$ is associated with a noun class that includes semantic forms pertaining mainly to 'long, rigid objects' including desiccated wooden objects (Walker 1966: 220).

The primary issue with which I am concerned here has to do with what should be adopted as the broader linguistic frame of reference for an adequate ethnolinguistic investigation of so-called kin terms. As Michael Silverstein declared in 1976, abstracted, nominal referential kin term forms have little if any value for anthropological linguistic study except as part of - where relevant - a broader pragmatic, morphosyntactic and semantic analysis of relational terminology systems in toto. It is unfortunate that Kroeber allowed theoretical blinders to shield from his analytic purview the rich cultural significance of relational terminology usages he observed both within and beyond a kinship context at Zuni. The pertinent fact is that Kroeber's full range of observed Zuni relational nomenclature usages are both linguistically valid and culturally significant.

Rather than a narrowly defined set of genealogically-based referential, nominal kin terms, we find in pragmatic use at Zuni-in 1917 as yet today-a role-based system of relational nomenclature that accords with what Anthony Carter (1984) identifies as a household-based relational terminology system. Regarding actual usages in this way greatly expands a nativistic understanding of Zuni social organisation. As ethnographers have long noted (e.g. Cushing 1979; Dozier 1970; Eggan 1950; Mindeleff 1891; Titiev 1967), the Western Pueblo of Zuni is fundamentally-that is culturally — a social system organised around a network of interconnected household groups. Social interaction at Zuni involves role relations and relative seniority based statuses appropriate to this household-group structure (Cushing 1979; Kroeber 1917: 103-09). Zuni 'families' are organised as a system of interlinked households and socioceremonially interconnected household groups. Kroeber (1917) was astute enough to comment on this obvious ethnographic fact many times over in his study. 
Yet, influenced by the anthropological canon of his time of applying the genealogical method in order to study the Zuni kinship system, Kroeber neglected to ground his analysis of the actual use of Zuni relational forms according to household group-based social relations. Almost all of the kin-term usage errata mentioned by Kroeber-as he himself notes-make sense in relation to factors of domestic and ceremonial household group relations (cf. also Eggan 1950: 188-90; Schneider and Roberts 1956: 18):

The house is basic in Zuni life ...

In daily life it is common residence, and known blood common to individuals, and even friendship and neighborliness, that count (Kroeber 1917: 48).

Allow me to close with some key ethnolinguistic facts—observed but not systemically accounted for by Kroeber-that serve to further corroborate what I classify as a 'nascent'-based - that is 'where one was raised, or from what household one has emerged'-as versus a 'descent'-based system of use of Zuni relational terminology.

First, one's 'family' may be referred to in Zuni as '(Hom [1 ${ }^{\text {st }}$ sg.poss.]) a:willi kyak'wen'ona'. Kroeber correctly noted that a direct translation for this expression is not (genealogically kin related) 'family' or even 'relatives' per se but rather, 'Those I grew up with in the same household'. Thus the question, 'Chuwap do' a:willi kyak'wen'ona?' translated broadly by Kroeber from an English frame of reference as 'Who is your family?' really translates: 'Who are those you grew up/emerged together with in the same household/household-group?'

An appropriate answer to the above question might be 'Hom i:yanikina:we'. Kroeber translated this expression into English as 'my (genealogical) relatives/kin'. However, Kroeber also correctly acknowledged that a more accurate translation of this Zuni relationship-establishing relational particle form in point of fact does not mean kin but rather, 'those one greets (with terms of relationship)'; or, lit., 'those whom are greeted by terms of relation to me (obj)'.

In 1986 I asked a man in his late nineties or early centenary years, 'Who are those who are i:yanikina:we to you?' His response was to explain that when he grew up in the Zuni farming village of Nutria, he was taught from an early age that, 'Everyone in your same village is your i:yanikina:we'. 
Hence he was to greet anyone within his own village with Zuni relational terminology forms, applying the principles of relative seniority and relative social proximity appropriately as the situation called for.

In sum, a study of variation in referential kin-term forms in terms of their kinship context-based prototypicality and extensional semantics does not amount to a full linguistic or ethnosemantic account of a broader relational terminology system; or at least it does not do so for Zuni. Silverstein framed the problem well:

Such lexical items as so-called kinship terms or personal names in any society can hardly be characterized by 'semantic' analysis. It is the pragmatic component that makes them lexical items to begin with ... it is the pragmatic functions that make them anthropologically important ... as Schneider, among others, have never ceased pointing out (Schneider 1965, 1968 [1976]). Further, so-called folk taxonomies of nominal lexical items, again 'semantically' analyzed by a procedure of ostensive reference, essentially ripped from the context of speech, give us no cultural insight (Silverstein 1976: 52).

Certainly there is nothing inherently objectionable with choosing to examine kin terminology as if it could be extracted and decontextualised linguistically from its broader social-semiotic field of relational terminology. Warren Shapiro notes (in Alés, Watts and Shapiro 2009; cf. Shapiro Chapter 1), indeed, that he 'learned to isolate the domain of kin term usage by locally pertinent questions' (Alés, Watts, and Shapiro 2009: 29), as is true for Bean with respect to her study of Kannada kin terminology $(1975,1978)$. I have no doubt that this could at least artificially be accomplished at Zuni, except that the assumptions thus imposed would be, I believe, culturally erroneous as traditional core praxis and belief. There are simply speaking no terms for 'true blood relatives' per se at Zuni. I was once told by a Zuni informant, when I asked about the value of tracing someone's 'blood relatives', that one should not count one's relations as it would be like counting sheep; accordingly, some might die.

The Zuni relational particle stem forms tsitda and datchu, for instance, simply are not focally or prototypically identified with nearest genealogical referents of genetrix and genitor. Folk definitions and focality data that I collected from a wide range of informants in 1986 revealed that these terms are focally associated with household-based or otherwise socially proximal relations-always - and that they shift in focal reference according to actual, 'on the ground' pragmatic relations, including 
nonkinship-based adoption into a household. Thus, for 10 key informants representing a range of age, gender and degrees of traditionality variables, only one claimed a genetrix as their focal member of the relational class ' $t$ sitda', whereas all 10 (including that same informant) claimed an elder, socially proximal female who had 'raised' the informant. This was true for all 'primary' relational terminology forms that informants mentioned in their relational histories which I collected prior to eliciting focality data (Watts 2000: 90). Folk definitions elicited for these core relational particle forms also emphasise roles and social proximity relations, rather than genealogical nearness, as primary (ibid.: 212-15).

Shapiro assumes (in Alés, Watts and Shapiro 2009: 29) that the fact that Zuni genealogically defined parents may be referred to by unmarked kinterm stem forms in contrast with in his view metaphorically 'extended', marked collateral forms associate genealogical focality semantically with the unmarked forms, but this misinterprets the Zuni data. The so-called marked, 'extended' relational forms attaching the independent particles tashhi (big/older) or ts'ana (little/younger) to tsitda and datchu or other relational particles do not indicate metaphorical extensions of genealogically nearest referent forms. Rather, these qualifying particles, when used at all, indicate relative seniority status within a role-based suprahousehold group cohort. If one's Tsitda (natal or core householdbased, primary female manager/caregiver) is not the eldest female of her natal or adoptive household-based female cohort group, then she is not directly in line to assume, for instance, the important ceremonial role of a Kuku (i.e. a Tsitda's husband's Tsitda's suprahousehold-group female cohort senior) for the speaker's suprahousehold group once a Datchu's (married-in husband of a Tsitda) natal Tsitdas have died. Someone needs to perform important ceremonial roles such as burials and naming ceremonies from the Datchu's (one's secondary) matricentric household group. In similar fashion that a Tsitd' tasshi may assume the role of one's ceremonial Kuku after the decedence of the original Kuku's immediate cohort set members, according to one informant a Kya' tasshi $(<$ kyakya + tashhi, eldest Kyaykya) may be called in to mediate a family conflict within a suprahousehold-group context, in order to facilitate an impartial yet caring hearing about the dispute.

One is said to be 'born into' one's natal, core domestic household group, while one is 'born for' one's secondary, affinally interlinked Datchu's natal household group (see Figure 33). One's Kyakya's (Tsitda's cohousehold group 'brother's) offspring from his wife's natal household are likewise 
'born for' one's own core household group. Accordingly then, one has ceremonial obligations with respect to one's Kyakya's wife's or tertiary household-group children.

Much of the semantic problem involved in anthropological misinterpretations of Zuni relational terminology arises from using English kin-type translations as assumed denotata for Zuni relational particle forms.

So long as the analyst is intent on isolating a narrowly defined, semantically nonfocal, morphosyntactically stripped subset of relational particle forms, ignoring wider pragmatic principles of alternation that would require including additional nomenclature and additional linguistic morphosyntactic elements in order to conduct a more holistic systemic analysis, then the cross-linguistic analysis of kin terminology can proceed - as indeed it has historically and often quite impressivelyaccording to a controlled, cross-cultural comparative framework. However, such an approach to the study of genealogically derived referential kinterm applications need not, I believe, be undertaken a priori or in the absence of a wider ethnolinguistic or potentially even a wider extensionist semantic analysis of relational terminology forms.

Zunis_-or at least those Zunis who have not been converted (as many by now have been) to Anglocentric assumptions about 'family', 'clanship', and 'kinship' - say that a genealogical approach is not what matters most to them; at least, it is not what matters first. Zunis are neither ignorant of nor blind to facts of blood relations or to the role of sexuality in producing offspring. Indeed, quite often, it may well be the case that blood ties are nearly congruent with role relations within a householdgroup system such that it is hardly necessary to distinguish between them. Nevertheless, the Zuni 'rule of thumb' that Kroeber acknowledged yet could not bring himself to represent as primary or core to the use of Zuni relational terminology is in fact a quite effective, flexible, culturally ingenious method for sustaining a traditional household-group and communal socioceremonial system over time (Cushing 1979). Principles of fission and fusion long acknowledged as vital in the ethnographic literature on Zuni and other western pueblos (Eggan 1950; Dozier, 1970) are performatively instantiated and indexicalised through utilising Zuni relational terminology according to degrees of actual social proximity, relative role-based seniority, and an inclusive/exclusive principle (Ladd 1979). 
Finally, as I have suggested elsewhere (Watts 2000: 24-29; and in Alés, Watts and Shapiro 2009), semantic extension rules could be applied to supraclasses and subclasses of Zuni relational terminology forms based on culturally attributed focal and extended usages (cf. Sheffler and Lounsbury 1971). Hence, I believe that Scheffler's use of extensionist semantics can be applied to a much broader spectrum of relational terminology than that elicited through a genealogical frame of reference alone. For example, while the prototypical, focal referent of i:yanikina:we would likely include those one has grown up or emerged with in the same household group, this form is extended semantically to interlinked secondary and tertiary suprahousehold groups and to wider 'clan'-interconnected households, as well as to one's initiatory kiva group or medicine society group, to ceremonial godparents' household-groups, to one's village as a whole, and to the political government council. Whether such a broadening of analytic scope might serve to help resolve the longstanding theoretical debate over 'old' versus new' 'kinship studies' (Shapiro Chapter 1) is yet to be seen. Notwithstanding, from a linguistic standpoint, widening the scope of study to a complete relational terminology system is not only possible but it would fill a major gap in our scholarly understanding of how relationship classificational systems operate in their entirety.

Focality data, classes and supraclasses of relational terminology, and even equivalence reduction rules for the extension of Zuni relational particle categories could be analysed in such manner as to throw light on universals of relational terminology systems overall. Factors such as degrees of social proximity, kinds of settings and situations and features such as familiar versus nonfamiliar, formal versus casual, and polite versus impolite (cf. Brown and Levinson 1978) might turn out to have been involved with the evolution of human cognition and pragmatic social interaction. Hence, cultural principles of use applying to the 'meaning potential' of relational terminology usages (Halliday 1973: 54)—though heuristically varying according to types of sociocultural organisation-might be indexicalised according to pragmatic selection and alternation rules in the use of relational terminology everywhere. Yet, we cannot discover such higher-order, possibly universal features or their typologically significant modes of variation if we do not examine relational terminology systems in their broadest linguistic scope.

For Zuni, relational terminology usages focally refer to immediate household group-based and/or socially proximal social relations. Zuni relational particle variants can be metaphorically extended to members 
of the suprahousehold group that includes 'clan' relations, on one hand, and to members of one's Datchu's (natal household married-in pater) and Kyakya's (out-married adult male of natal household's) affinally interlinked household groups, on the other. Additionally, Zuni relational terms can be metaphorically extended to members of one's kiva group and medicine society. These are culturally conceptualised as ceremonial household groups (cf. Eggan 1950: 190-93), such that relational particles are used to frame role relations involving seniority and reciprocal role obligations within these groups as well as within familial household-group units.

I:yanikina:we (lit., those one greets by relational particle forms) also may include and be extended by appropriate relational terminology usages to 'godparental' relations and members of their household groups, also to all official political and religious leaders, or even to a close friend's (kuwaye) cohousehold-group members, and ultimately to members of one's entire neighbourhood, village, tribe, or historical alliance group (e.g. familially interrelated Hopi clan members). Principles involved in the pragmatic use of Zuni relational terminology—including the inclusive/exclusive principle, degrees of relative social proximity, ceremonial sponsorship and relative seniority within and beyond the immediate household-have facilitated an enduring flexibility in the traditional role-based organisation of molecular household-group units and their wide-reaching extensions for many centuries. They remain vital to maintaining traditional values at Zuni Pueblo today.

\section{References}

Alés, Catherine, Linda K. Watts and Warren Shapiro. 2009. 'Discussion of "A.L. Kroeber and the new kinship studies"'. Anthropological Forum: A Journal of Social Anthropology and Comparative Sociology 19(1): 21-31. doi.org/10.1080/00664670802695426

Basso, Ellen B. 1973. 'The use of Portuguese relationship terms in Kalapalo (Xingu Carib) encounters: Changes in a Central Brazilian communications network'. Language in Society 2(1): 1-21. doi.org/ $10.1017 /$ S0047404500000038

Basso, Keith and Henry A. Selby (eds). 1976. Meaning in Anthropology. Albuquerque: University of New Mexico Press. 
Bean, Susan S. 1975. 'Referential and indexical meanings of amma in Kannada: Mother, woman, goddess, pox, and help!' Journal of Anthropological Research 31(4): 313-30. doi.org/10.1086/jar.31.4. 3629884

- 1978. Symbolic and Pragmatic Semantics: A Kannada System of Address. Chicago: University of Chicago Press.

Bloch, Maurice. 1971. 'The moral and tactical meanings of kinship terms'. Man (n.s.) 6(1): 79-87. doi.org/10.2307/2798429

Boas, Franz. 1923. 'The relationship system of the Vandau'. In Race, Language, and Culture, edited by Franz Boas, 384-96. New York: Free Press.

Brown, Penelope and Stephen Levinson. 1978. 'Universals in language usage: Politeness phenomena'. In Questions and Politeness: Strategies in Social Interaction, edited by Esther N. Goody, 56-289. Cambridge Papers in Social Anthropology, no. 8. New York: Cambridge University.

Burling, Robbins. 1964. 'God's truth or hocus pocus?' In Cognitive Anthropology, edited by Stephen Tyler, 419-27. Prospect Heights, IL: Waveland Press.

Carsten, Janet. 2000. Cultures of Relatedness: New Approaches to the Study of Kinship. Cambridge: Cambridge University Press.

Carter, Anthony T. 1984. 'Household histories'. In Households: Comparative and Historical Studies of the Domestic Group, edited by Robert McC. Netting, Richard R. Wilk and Eric J. Arnould, 44-83. Berkeley: University of California Press.

Conant, Francis P. 1961. 'Jarawa kin systems of reference and address: A componential comparison'. Anthropological Linguistics 3(2): 19-33.

Cushing, Frank Hamilton. 1979. 'Outline of Zuni mytho-sociologic organization'. In Zuni: Selected Writings of Frank Hamilton Cushing, edited by Jesse Green, 185-93. Lincoln: University of Nebraska Press. First published in Popular Science Monthly (June 1882): 186-92.

Dozier, Edward P. 1970. The Pueblo Indians of North America. New York: Holt, Rinehart, and Winston.

Eggan, Fred. 1950. The Social Organization of the Western Pueblos. Chicago: University of Chicago Press. 
Fawcett, Robin P. 1984. 'System networks, codes, and knowledge of the Universe'. In The Semiotics of Culture and Language, vol. 2, edited by Robin P. Fawcett, M.A.K. Halliday, Sydney M. Lamb and Adam Makkai, 135-179. London: Frances Pinter Publishers.

Fawcett, Robin P., M.A.K. Halliday, Sydney M. Lamb and Adam Makkai (eds). 1984. The Semiotics of Culture and Language, vol. 2. London: Frances Pinter Publishers.

Goodenough, Ward H. 1956. 'Componential analysis and the study of meaning'. Language 32(1): 195-216. doi.org/10.2307/410665

Goody, Esther N. (ed.). 1978. Questions and Politeness: Strategies in Social Interaction. Cambridge Papers in Social Anthropology, No. 8. New York: Cambridge University.

Goody, Jack (ed.). 1958. The Developmental Cycle in Domestic Groups. Cambridge: Cambridge University Press.

Green, Jesse (ed.). 1979. Zuni: Selected Writings of Frank Hamilton Cushing. Lincoln: University of Nebraska Press.

Halliday, Michael A.K. 1973. Explorations in the Functions of Language. London: Edward Arnold Publishers.

__. 1978. Language as Social Semiotic. Baltimore, MD: University Park Press.

Hocart, A.M. 1937. 'Kinship systems'. Anthropos 32: 545-51.

Holland, Maximilian. 2004. 'Social bonding and nurture kinship: Compatibility between cultural and biological approaches'. PhD thesis. London School of Economics.

Keesing, Roger M. 1969. 'On quibblings over squabblings of siblings: New perspectives on kin terms and role behavior'. Southwestern Journal of Anthropology 25(3): 207-27. doi.org/10.1086/soutjanth.25.3.3629275

__ 1970. 'Toward a model of role analysis'. Handbook of Method And Theory in Cultural Anthropology, edited by Raoul Naroll and Ronald Cohen, 423-53. New York: Columbia University Press. 
Klar, Kathryn, Margaret Langdon and Shirley Silver (eds). 1970. 'Toward a model of role analysis'. In Handbook of Method and Theory in Cultural Anthropology, edited by Raoul Narroll and Ronald Cohen, 423-53. New York: Columbia University Press.

- 1980. American Indian and Indoeuropean Studies: Papers in Honor of Madison S. Beeler. The Hague: Mouton. doi. org/10.1515/9783110808681

Kroeber, A.L. 1917. 'Zuni kin and clan'. Anthropological Papers of the American Museum of Natural History 18(2): 39-204.

Ladd, Edmund J. 1979. 'Zuni social and political organization'. In Handbook of North American Indians, Volume 9: The Southwest, edited by Alfonso Ortiz, 482-91. Washington, DC: Smithsonian Institution.

Leach, Edmund. 1958. 'Concerning Trobriand clans and the kinship category "tabu"'. In The Developmental Cycle in Domestic Groups, edited by Jack Goody, 120-45. Cambridge: Cambridge University Press.

Leaf, Murray J. 1971. 'The Punjabi kinship terminology as a semantic system'. American Anthropologist 73(3): 545-54. doi.org/10.1525/ aa.1971.73.3.02a00020

Mindeleff, Cosmos. 1891. 'A study of Pueblo architecture in Tusayan and Cibola'. Eighth Annual Report of the Bureau of American Ethnology for the Years 1886-1887. Washington, DC: Government Printing Office, 3-228. Online: archive.org/details/tusayancibola00mindrich (accessed 9 June 2017).

Morgan, Lewis Henry. 1871. Systems of Consanguinity and Affinity of the Human Family. Washington, DC: Smithsonian Institution.

Murdock, George P. 1949. Social Structure. New York: Macmillan.

Narroll, Raoul and Ronald Cohen (eds). 1970. Handbook of Method and Theory in Cultural Anthropology. New York: Columbia University Press.

Needham, Rodney. 1962. 'Genealogy and category in Wikmunkan Society'. Ethnology 1(2): 223-64. doi.org/10.2307/3772877

Netting, Robert McC., Richard R. Wilk and Eric J. Arnould (eds).1984. Households: Comparative and Historical Studies of the Domestic Group. Berkeley: University of California Press. 
Newman, Stanley. 1955. 'Vocabulary levels: Zuni sacred and slang usage'. Southwest Journal of Anthropology 11(4): 345-54. doi.org/10.1086/ soutjanth.11.4.3628910

__. 1958. 'Zuni dictionary'. International Journal of American Linguistics 24(1): part II.

—_. 1965. Zuni Grammar. University of New Mexico Publications in Anthropology no. 14. Albuquerque, NM: University of New Mexico Press.

Ortiz, Alfonso (ed.). 1979. Handbook of North American Indians, Volume 9: The Southwest. Washington, DC: Smithsonian Institution.

Rivers, William H.R. 1910. 'The genealogical method of anthropological enquiry'. Sociological Review 3(1): 1-12. doi.org/10.1111/j.1467954X.1910.tb02078.x

Scheffler, Harold W. and Floyd G. Lounsbury. 1971. A Study in Structural Semantics: The Siriono Kinship System. Englewood Cliffs, NJ: Prentice Hall.

Schneider, David M. 1980. American Kinship: A Cultural Account. 2nd edition. Chicago: The University of Chicago Press.

- - 1984. A Critique of the Study of Kinship. Ann Arbor: University of Michigan Press. doi.org/10.3998/mpub.7203

Schneider, David M. and John Roberts. 1956. Zuni Kin Terms. Notebook no. 3, Laboratory of Anthropology. Lincoln, NB: University of Nebraska Press.

Seiler, Hansjakob. 1980. 'Two systems of Cahuilla kinship expressions: Labeling and descriptive'. In American Indian and Indoeuropean Studies: Papers in Honor of Madison S. Beeler, edited by Kathryn Klar, Margaret Langdon and Shirley Silver, 229-36. The Hague: Mouton. doi.org/10.1515/9783110808681.229

—_. 1982. 'Inherent versus established relation, proximity versus obviation, and two types of Cahuilla kinship expressions'. International Journal of American Linguistics 48(2): 185-96. doi.org/ $10.1086 / 465727$

Service, Elman. 1985. A Century of Controversy: Ethnological Issues from 1860-1960. New York: Academic Press. 
Shapiro, Warren. 2009. 'A.L. Kroeber and the new kinship studies'. Anthropological Forum 19(1): 1-20. doi.org/10.1080/ 00664670802695418

Silverstein, Michael. 1976. 'Shifters, linguistic categories, and cultural description'. In Meaning in Anthropology, edited by Keith Basso and Henry A. Selby, 11-56. Albuquerque: University of New Mexico Press.

Smith, Watson and John Roberts. 1954. Zuni Law: A Field of Values. Papers of the Peabody Museum of American Archaeology and Ethnology, Harvard University 43(1). Reports of the Rimrock Project, Values Series 4. Cambridge, MA: Peabody Museum.

Swartz, Marc J. 1960. 'Situational determinants of kinship terminology'. Southwestern Journal of Anthropology 16(4): 393-97. doi.org/10.1086/ soutjanth.16.4.3628884

Titiev, Mischa. 1967. 'The Hopi use of kinship terms for expressing sociocultural values'. Anthropological Linguistics 9(5): 44-49.

Walker, Willard. 1966. 'Inflectional class and taxonomic structure in Zuni'. International Journal of American Linguistics 32(3): 217-27. doi.org/10.1086/464906

Wallace, Anthony F.C. 1965. 'The problem of the psychological validity of componential analysis'. American Anthropologist 67(5): 229-48. doi.org/10.1525/aa.1965.67.5.02a00800

- 1970. 'A relational analysis of American kinship terminology'. American Anthropologist (n.s.) 72(4): 841-45. doi.org/10.1525/aa. 1970.72.4.02a00090

Wallace, Anthony F.C. and John Atkins. 1960. 'The meaning of kinship terms'. American Anthropologist 62(1): 58-80. doi.org/10.1525/aa. 1960.62.1.02a00040

Watts, Linda K. 1992. 'Relational terminology at Zuni Pueblo: A social semiotic case study'. PhD dissertation, Arizona State University.

—. 1997. 'Zuni family ties and household group values: a revisionist cultural model of Zuni social organization'. Journal of Anthropological Research 53(1): 17-29. doi.org/10.1086/jar.53.1.3631113

- 2000. The Social Semiotics of Relational Terminology at Zuni Pueblo. Mellen Studies in Anthropology, vol. 3. Lewiston, NY: Edwin Mellen Press. 
This text is taken from Focality and Extension in Kinship: Essays in Memory of Harold W. Scheffler, edited by Warren Shapiro, published 2018 by ANU Press, The Australian National University, Canberra, Australia.

doi.org/10.22459/FEK.04.2018.09 